\title{
Heritable and nutritional influences on bone mineral mass
}

\author{
S. Ferrari, R. Rizzoli, and J-P. Bonjour \\ Division of Bone Diseases, WHO Collaborating Center for Osteoporosis and Bone Diseases, Department of \\ Internal Medicine, University Hospital, Geneva, Switzerland
}

ABSTRACT. Osteoporosis is the net result of the maximal amount of bone mineral mass achieved by the end of pubertal growth (peak bone mass) minus post-menopausal and elderly bone losses. Peak bone mineral mass is determined from early childhood by both heritable and environmental factors. Recent developments in the molecular epidemiology of osteoporosis have shown the interest, but also the limitations, of specific molecular markers, such as the vitamin $D$ receptor gene polymorphisms Bsm 1 and Fok 1, to explain bone mineral density differences across the population. Importantly, however, interactions between VDR gene polymorphisms and environmental factors, particularly dietary calcium, have provided new insights into the complex determination of bone mineral mass.

(Aging Clin. Exp. Res. 10: 205-213, 1998)

๑1998, Editrice Kurtis

\section{INTRODUCTION}

Osteoporosis is a common disorder which depends on both the amount of bone mineral mass acquired during growth, and postmenopausal as well as age-related bone losses. Although a vast majority of studies aiming at preventing the occurrence of osteoporotic fractures focused on slowing bone mineral density (BMD) losses by a variety of dietary and pharmacologic interventions, the risk of osteoporosis up to the seventh decade is mostly determined by peak bone mineral mass. Therefore, the determinants of BMD growth during childhood have recently emerged as essential factors to understand the prevalence of osteoporosis.

We review here the influence of heritable and dietary factors on bone mineral mass acquisition in childhood and maintenance in aging adults, with particular attention to the interaction between calcium intake and recently identified allelic polymorphisms in the vitamin $\mathrm{D}$ receptor gene.

\section{BONE MINERAL MASS HEREDITY}

Non-invasive techniques capable of measuring BMD with great precision and accuracy, such as dual X-ray absorptiometry (DXA) (1), have led to a clear definition of osteoporosis, which is a BMD below minus 2.5 standard deviations from the mean BMD in young adults of the same sex, and consequently to estimate the relative risk of skeletal fractures in relation to BMD (2), although many other factors certainly play a role in the occurrence of osteoporotic fractures. An evaluation of health status, dietary and life-style habits, as well as a family history of osteoporosis, may orient towards an increased risk of osteoporotic fractures (3).

Concerning the importance of a positive family history of osteoporosis, indeed it was shown that daughters of osteoporotic females had a decreased BMD (4). Moreover, several studies have established clear evidence for a familial resemblance of bone mineral mass, and demonstrated that a fair amount of the BMD variance across the population could be explained by genetic factors, which are known as heritability (5). For this purpose, two kinds of human models have been used. In the twin model, within-pairs correlations for BMD are compared between monozygotic (MZ) twins, who by essence share 100\% of their genes, and dizygotic twins, who have 50\% of their genes in common. Stronger correlation coefficients among adult $\mathrm{MZ}$ as compared to $\mathrm{DZ}$ twins are indicative of a strong genetic influence on peak bone mineral mass, accounting for as much as $80 \%$ of lumbar spine and proximal femur BMD (6). Parents-

Key words: Calcium intake, heredity, osteoporosis, peak bone mass, polymorphism, vitamin D receptor.

Correspondence: S. Ferrari, M.D., Division of Bone and Mineral Metabolism, Beth Israel Deaconess Medical Center, Harvard Institute of Medicine, 77, Ave. Louis Pasteur, Boston, MA 02115, U.S.A.

Received and accepted April 3, 1998. 
offspring comparisons have also shown significant relationships for BMD, albeit heritability estimates have been somewhat lower (in the range of 60\%) than in the twin model (7). Actually, the magnitude of direct genetic effects on peak bone mineral mass as evaluated in such human models may be overestimated by similarities in environmental covariates $(8,9)$, as well as by indirect genetic effects on bone mass through the determination of lean body mass (10).

In an attempt to redefine the actual heritability for bone mineral mass, as well as establish the age at which genetic factors operating on various bone mineral mass constituents are expressed, we recently investigated correlations for bone mineral content (BMC, g), areal and volumetric bone mineral density (BMD, $\mathrm{g} / \mathrm{cm}^{2}$ and $\mathrm{BMAD}, \mathrm{g} / \mathrm{cm}^{3}$, respectively) and bone area $\left(\mathrm{BA}, \mathrm{cm}^{2}\right)$ at the lumbar spine (LS) and femur (neck, FN, trochanter, FT, and diaphysis, FS) in 138 premenopausal women (mean age $\pm \mathrm{SD}$, $40.0 \pm 4.0$ years) and their prepubertal daughters (8.1 \pm 0.7 years) (11). Regressions were further adjusted for height, weight and calcium intake, such as to minimize the impact of indirect genetic effects, as well as of dietary influences on bone mineral mass re- semblance among relatives. The results indicated that despite great disparities in the maturity of the various constituents of bone mineral mass before puberty with respect to peak adult values, ranging from 33\% for LS BMC to $100 \%$ for FN BMAD, heredity by maternal descent was detectable at all skeletal sites, and affected virtually all bone mineral mass constituents (Fig. 1). Moreover, when daughters bone values were reevaluated two years later, when puberty had begun and bone mineral mass had considerably increased, measurements were highly correlated with prepubertal values (all $r>0.80$ ), whereas mother-daughter correlations had remained unchanged.

By the age of 16 to 18 years in females, and 18 to 20 years in males, bone mineral mass growth virtually ceases, but a marked scattering of BMD values for both genders is then apparent across the population $(12,13)$. A major proportion of this variance is due to genetic factors which are already expressed before puberty, with subsequent tracking of bone mineral mass constituents through the phase of rapid pubertal growth until peak bone mass is achieved.

In contrast, it is presently unclear whether genetic effects also operate on bone turnover and the rate of
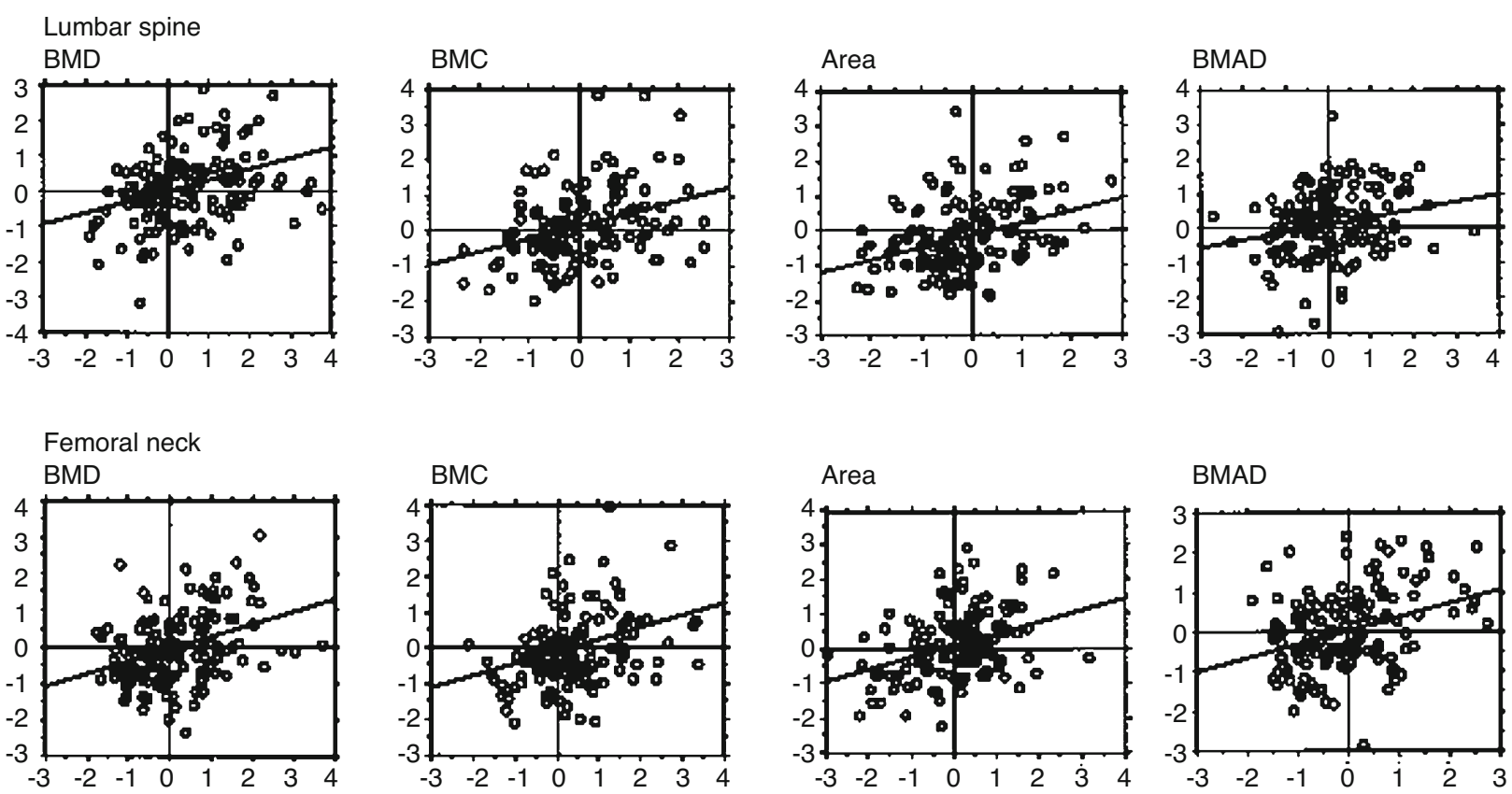

Figure 1 - Correlations of bone mineral mass constituents between prepubertal daughters and their premenopausal mothers. Areal bone mineral density $\left(B M D, \mathrm{~g} / \mathrm{cm}^{2}\right.$ ), bone mineral content (BMC, $\mathrm{g}$ ), bone area (Area, $\mathrm{cm}^{2}$ ) and volumetric bone mineral density (BMAD, $\mathrm{g} / \mathrm{cm}^{3}$ ) were standardized for age (Z-scores). Pearson's correlation coefficients ( $\mathrm{r}$ ) for the various measures were 0.31-0.36 at both lumbar spine and femoral neck, except lumbar spine BMAD ( $\mathrm{r}=0.24)$. All were significant at $\mathrm{p}<0.01$. Adapted from Ferrari S. et al.(11), with permission. 
post-menopausal and age-related bone losses (5). In this regard, an important, although often overlooked, analysis of familial resemblance for bone mineral mass expanding over three generations showed an absence of correlations between grand-mothers and their grand-daughters BMD (14), suggesting that nongenetic, generation-related factors (such as secular trends for changes in nutrient intake) and/or postmenopausal estrogen deprivation could overcome genetic effects on peak bone mineral mass in the later determination of osteoporosis (14).

\section{NUTRITION AND BONE MINERAL MASS}

As opposed to the predominant genetic effects on bone mineral mass acquisition, rather than maintenance and rate of loss, nutritional factors have long been considered to exert a major influence on the risk and prevention of osteoporosis during late life years. A body of epidemiological and prospective studies have indeed indicated the importance of protein intake (15-17) and mostly calcium and vitamin D (18-23) for maintaining BMD and decreasing the incidence of osteoporotic fractures in the elderly.

Increasing calcium intake during childhood and adolescence has more recently also been advocated in order to improve bone mineral accrual during growth, and thereby potentially increase peak bone mineral mass (24). Analyses of the relationships between $\mathrm{BMD}$ and spontaneous calcium intake in the young, however, show a poor and sometimes absent correlation between these two variables (25). A few prospective randomized intervention trials examined the effects of calcium supplements in children and adolescents, and found variable influences according to the subject's age, the skeletal sites examined and the baseline calcium intake (26-28). Nevertheless, we recently demonstrated a remarkable increase in BMD gain in the appendicular skeleton in 144 prepubertal girls receiving calcium-supplements ( $850 \mathrm{mg} /$ day) for one year, compared with placebo, particularly when their spontaneous calcium intake was less than $880 \mathrm{mg} /$ day (the median of the cohort), a value similar to the RDA at that age (Fig. 2). Interestingly, in that study we observed that calcium supplements not only positively influenced BMD gain, but also bone area and height. This suggests that calcium was effective on the various constituents of bone mineral mass. Although it has not yet been proven that early dietary intervention, such as increasing calcium intake in childhood, will result in a determinant increase in peak bone mineral mass, our observation of increased bone dimensions, and persistant BMD differences between calcium and placebo-treated subjects one

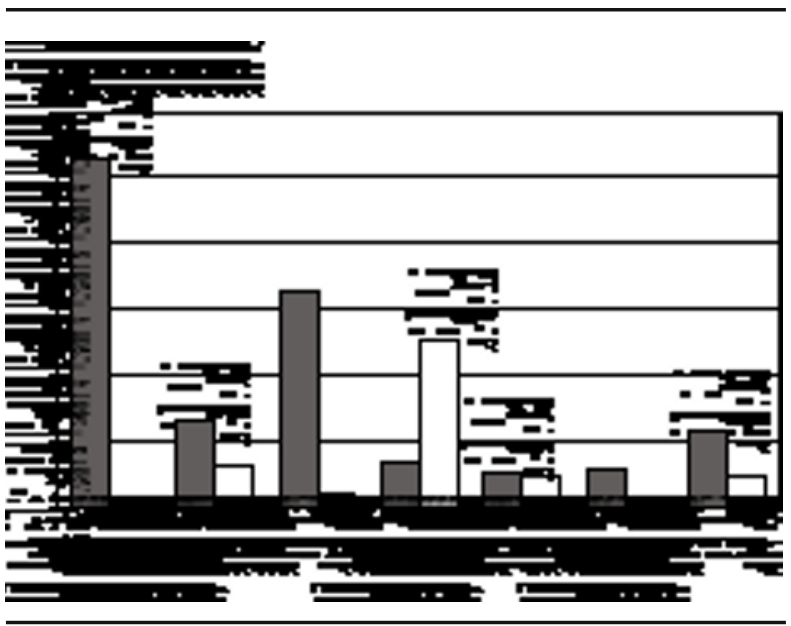

Figure 2 - Effects of calcium supplements on BMD gain in prepubertal girls. The percentage increase in BMD gain at various skeletal sites over one year due to calcium supplements (850 $\mathrm{mg} /$ day) was calculated as the mean BMD gain in the calcium group minus the mean BMD gain in the placebo group divided by the mean BMD gain in the placebo group. "All" is the average of the six skeletal sites as shown. Dotted and open bars indicate subjects with spontaneous calcium intake respectively below and over the median of the entire cohort $(880 \mathrm{mg} /$ day). ${ }^{*} \mathrm{p}<0.05 ; \# \mathrm{p}<0.01$ Adapted from Bonjour J-P. et al. (28), with permission.

year after cessation of the trial suggests that a higher bone mineral mass achieved during childhood might be maintained later on (28).

In summary, peak bone mineral mass is determined by both genetic and environmental factors which, either independently or through some mutual interactions, model the various constituents of apparent BMD from early childhood. On the other hand, hormonal and environmental factors seem to play a predominant role in bone remodeling and bone loss. The role of genetics in the latter phenomenon, however, still has to be elucidated (see below) (Fig. 3).

\section{VITAMIN D RECEPTOR GENE POLYMORPHISMS AND BONE MINERAL MASS}

DNA single base variations scattered through the human genome are known as allelic polymorphisms if they occur in at least $1 \%$ of the general population. Such polymorphisms constitute markers of the genetic diversity between individuals, and are potentially interesting tools in order to identify a heritable predisposition to common disorders, such as arteriosclerosis or diabetes (29). More recently, the characterization 


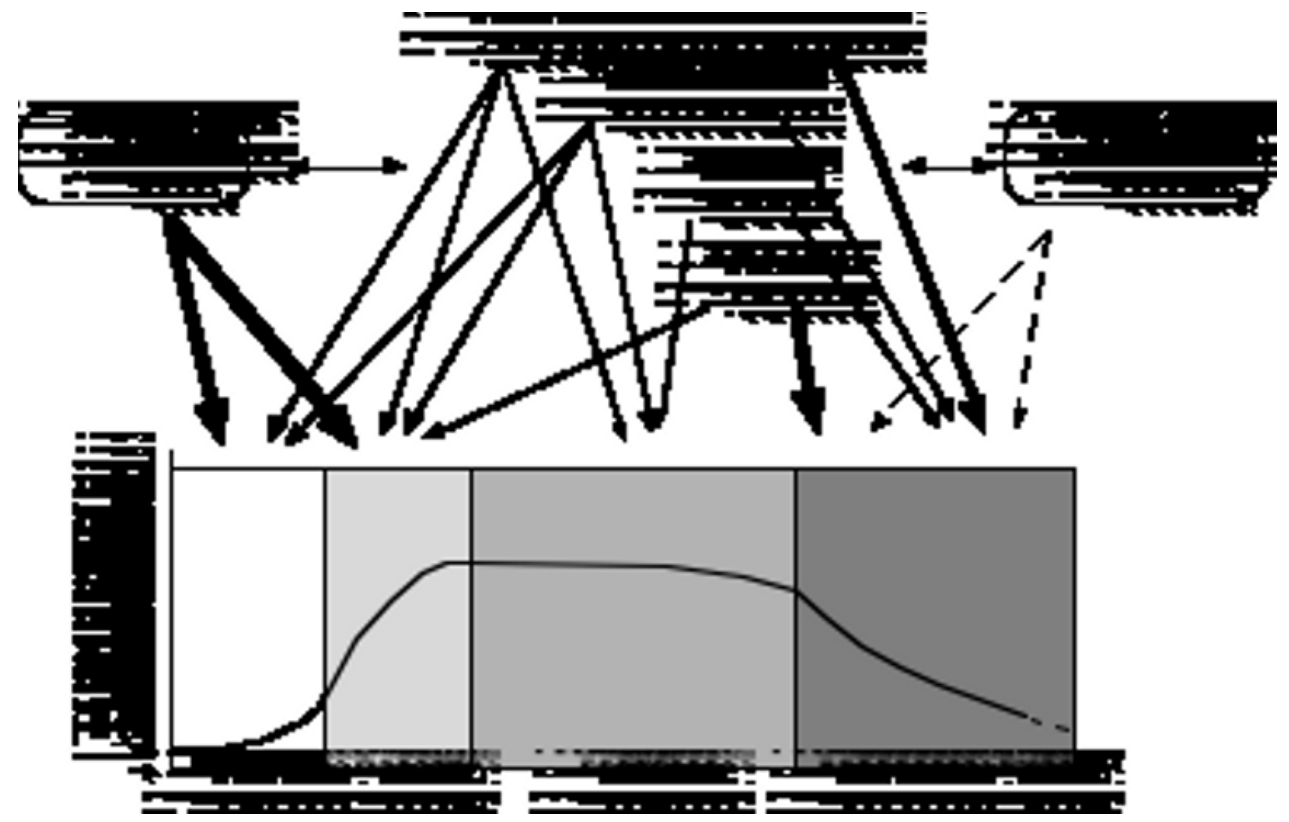

Figure 3 - Genetic and non-genetic influences on bone mineral mass. Arrow thickness indicates the relative importance of the various factors on bone mineral mass at different time points throughout life. Dotted arrows mean that there is yet no definite proof of an effect at this level. Double arrow-heads indicate potential interactions between genetic and non-genetic factors.

of polymorphic loci in genes coding for molecules implicated in bone structure and metabolism has given rise to an impressive number of molecular epidemiology investigations in the field of osteoporosis as well. Among the various candidate genes which have been more or less successfully associated with BMD (Table 1), the Vitamin $\mathrm{D}$ receptor alleles are by far the most extensively analyzed and the better defined.

\section{VDR-3' allelic polymorphisms}

Among a number of common allelic polymorphisms in the 3'-end region of the VDR gene, the one recognized by the endonuclease restriction enzyme Bsm 1 appears to be the most informative (30, 31 ), (another polymorphic site, Taq 1, in close vicinity to $B s m$, and therefore in perfect linkage disequilibrium with $B s m$ 1, has also been alternatively used in some association studies, in which case, $\mathrm{tt}$, Tt and TT genotypes are equivalent to $\mathrm{BB}, \mathrm{Bb}$ and $\mathrm{bb}$, respectively). Thus, genotypes $\mathrm{BB}$ (prevalence in the Caucasian population, 15\%), Bb (50\%) and bb (35\%), were first associated with significant differences in mean osteocalcin levels in a mixed cohort of both healthy males and females, particularly the subgroup of postmenopausal women (30). Morrison et al. later observed a marked reduction in BMD vari- ance among DZ twins sharing identical VDR 3 '-end alleles (31), which was suggestive of their major contribution to the genetic determination of BMD. Unfortunately, these results seemed to be weakened by some technical and analytical errors. The most important observations, however, were the lower BMD at the lumbar spine and proximal femur associated with the $\mathrm{B}$ allele in adult twins of both genders, as well as in unrelated pre- and postmenopausal women, both of European descent, and the higher rate of bone loss after menopause (31).

A large number of subsequent studies reported highly controversial results concerning the relationship between BMD or bone turnover and VDR-3' allelic polymorphisms $(32,33)$. Indeed, other workers failed to detect significant osteocalcin differences among VDR-3' alleles, or in the level of several markers of bone resorption $(34,35)$. Linkage studies in twins did not confirm a significant association of VDR-3' gene polymorphisms and BMD heritability (36). Regarding association studies between BMD and VDR-3' alleles, some workers confirmed a lower BMD in relation to the $\mathrm{B}$ allele in adults $(37,38)$, others found lower $\mathrm{BMD}$ values in homozygous subjects with the common $\mathrm{bb}$ or the rare bbAA genotypes rather than in $\mathrm{BB}$ sub- 
Table 1 - Candidate polymorphic gene markers associated with bone mineral mass.

\begin{tabular}{|c|c|c|}
\hline Genes & Polymorphic markers & References No. \\
\hline Vitamin D receptor (VDR)-3' & $\begin{array}{c}\text { Bsm } 1 \text { (alternatively, Taq 1) } \\
\text { Apa } 1\end{array}$ & 31 \\
\hline Vitamin D receptor (VDR)-5' & Fok 1 & 47 \\
\hline Collagen type I (COL1A1)-Sp1 binding site & Msc I & 63 \\
\hline Estrogen receptor (ER) & $\begin{array}{l}\text { Pvu II } \\
\text { Xba I }\end{array}$ & 65 \\
\hline Transforming growth factor (TGF) $\beta$ & $*$ & 67 \\
\hline
\end{tabular}

jects $(39,40)$, and most large scale studies in several Western populations as well as a meta-analysis failed to detect a significant association between BMD or BMD changes and VDR-3' alleles (Bsm 1) before or after menopause $(34,35,41,42)$. It therefore appears that VDR-3' alleles per se are unlikely to predict low bone mineral mass at the time of menopause, and cannot be considered useful markers of an increased osteoporosis risk.

Nevertheless, an association between bone mineral mass and VDR-3' alleles seems to be present in children $(43,44)$ and young adults $(45,46)$. Consequently, significant BMD differences, which may be detected in the young but are no longer present in mature adults from the same genetic background $(44,45)$, suggest that interactions between genetic and age-related as well as environmental factors may occur.

\section{VDR-5' allelic polymorphisms}

Very recently, independent polymorphisms in the VDR-5' start codon, identified by the restriction enzyme Fok 1 as FF (35\%), Ff (50\%) and ff (15\%), were reported to be associated with lumbar spine or femoral neck BMD differences in postmenopausal Mexican-American women (47), and premenopausal American white women (48), with ff subjects having the lowest mean BMD values; however, this association was not detected in black women. A recent report from Japan also found decreased BMD in ff subjects (49). In contrast, one European study in healthy premenopausal women (50), and another in young adult women as well as prepubertal girls (51) did not confirm significant relationships between BMD and VDR-5' start codon polymorphisms. Interestingly however, in the latter study we observed a possible genotypic in- teraction between VDR-3' (Bsm 1) and VDR-5' (Fok 1) polymorphic loci, since the lowest $\mathrm{BMD}$ values were found in BBff or BBFf subjects while bbFF females had the highest BMD.

\section{VDR-3' ALLELIC POLYMORPHISMS AND DIETARY CALCIUM INTERACTIONS}

Bone mineral mass determination has long been postulated to depend on gene-environment interactions as well (52; Fig. 3). We first observed an interaction between VDR-3' allelic polymorphisms and dietary calcium in a vitamin $\mathrm{D} /$ calcium-supplementation trial addressing $\mathrm{BMD}$ changes in the elderly; the mean rate of lumbar spine $\mathrm{BMD}$ loss was higher in $\mathrm{BB}$ than bb or $\mathrm{Bb}$ subjects (53). A significant positive correlation between calcium intake and BMD changes was observed only in $\mathrm{Bb}$ subjects, suggesting that the range of dietary calcium intake affecting BMD may differ among VDR-3' genotypes. In agreement with this hypothesis, it was later shown that BB postmenopausal women who had more prominent bone loss than females with other VDR genotypes also had a better response in terms of BMD changes to calcium supplements (54). Although some discordant findings about a possible association between postmenopausal bone loss and VDR-3' alleles $(35,41)$ may be related to the influence of the time since menopause on the physiology of bone loss $(54,55)$, additional studies have now reported a significant interaction between vitamin $\mathrm{D}$ and/or calcium intake and VDR-3' alleles on post-menopausal BMD (56-58).

Two recent investigations also found significant VDR-3'/dietary calcium interactions on BMD in young adults (59) and children (44). Thus, we observed that BMD gain in prepubertal girls was in- 
creased at several skeletal sites in $\mathrm{Bb}$ and $\mathrm{BB}$ subjects in response to calcium supplements $(800 \mathrm{mg} / \mathrm{d})$, whereas it remained apparently unaffected in bb girls, who had a trend for spontaneously higher BMD accumulation on their usual calcium diet. Moreover, other potential gene-environmental interactions, such as those involving physical exercise (60), as well as gene-gene interactions (see above) might modulate BMD-VDR-3' genotype relationships independently of dietary calcium.

In support of an interaction between dietary calcium and VDR-3' alleles, a decreased fractional 45Ca absorption has been found in $\mathrm{BB}$ as compared to bb late postmenopausal women receiving a low, as opposed to a high, calcium diet (61). Decreased intestinal calcium absorption has also been found in $\mathrm{BB}$ black American postmenopausal women (62). Interestingly though, differences in intestinal calcium absorption might also play a role in the apparent influence of dietary calcium levels on the relationship between BMD and VDR-5' start codon polymorphisms $(48,51)$.

\section{OTHER GENE POLYMORPHISMS AND BONE MINERAL MASS}

Many genes coding for structural bone proteins, calcium and phosphate regulatory hormones or modulators of bone turnover, including various hormones and cytokines, could potentially be involved in the polygenic determination of osteoporosis. A few of these candidate polymorphic genes, besides 3'- and 5'vitamin $\mathrm{D}$ receptor alleles, have recently been associated with $\mathrm{BMD}$ and/or the prevalence of osteoporosis in some populations (Table 1).

A polymorphism in the first intron of the COL1A1 gene (coding for Type I collagen, the major bone matrix protein), corresponding to a recognition site for the Sp1 transcription factor, has been associated with significant BMD differences at the level of the lumbar spine in postmenopausal women (63). Moreover, COL1A1 Sp1 genotypes Ss and ss, which represented 34\% and 3\%, respectively, of the study cohort, were more frequent among women with a vertebral fracture, as compared to women without it (63). In contrast, COL1A1 Sp1 polymorphisms were not associated with femoral neck BMD, an unexpected finding since Type I collagen is the major bone constituent of the entire skeleton. Another large population-based study in postmenopausal women, however, found an association between COL1A1 Sp1 polymorphisms and lumbar spine as well as femoral neck BMD (64), even though the average BMD difference among genotypes at the femoral neck level was about 0.2 standard deviations, and detectable only above the age of 70 , which remains of questionable biological relevance. On the other hand, odds ratios for prevalent vertebral fractures were not significantly different among the COL1A1 Sp1 genotypes. Interestingly, both studies suggested that the influence of COL1A1 Sp1 polymorphisms on BMD could be more prominent in older subjects. These observations need to be further substantiated by physiological and molecular evidence of altered collagen metabolism, such as the excretion of collagen $\mathrm{N}$-telopeptide breakdown products (NTX) for instance, in relation to COL1A1 Sp1 polymorphisms.

Pvu II and Xba I restriction fragment length polymorphisms in the first intron of the estrogen receptor gene have also been found to be associated with BMD in postmenopausal Japanese women, however, without apparent changes in several markers of bone turnover (65). These observations were not confirmed in a similar cohort from Korea (66), and estrogen receptor allelic polymorphisms have not been thoroughly investigated in European Caucasian and American populations.

In addition, two sequence variations were identified in the TGF- $\beta 1$ gene that might alter the structure of the protein (see legend of Table 1) (67). These two polymorphisms have been related to an increased risk of osteoporosis among Danish women. However, both TGF- $\beta 1$ mutant alleles were quite uncommon, which therefore makes it unlikely that they account for the high prevalence of osteoporosis in Western populations.

\section{CONCLUSIONS}

Osteoporosis, which depends on peak bone mineral mass as well as the rate of age-related bone loss, is a complex disorder determined by both genetic and non-genetic factors. The recent emergence of candidate genes potentially associated with BMD and bone turnover has provided an immense impetus towards the identification of a heritable susceptibility for osteoporosis. Among these genes, common allelic polymorphisms in the 3'-end region and the 5'-start codon region of the VDR gene have been the most extensively investigated. Whereas these polymorphic loci per se do not appear as definite molecular markers of osteoporosis, they have provided a new insight into the genetic determination of peak bone mineral mass, and re-updated the possibility of genetic influences on bone remodeling and bone loss. More importantly, they have emphasized that genetic and environmental influences on bone mineral mass cannot be easily dissociated. 


\section{REFERENCES}

1.Rizzoli R., Slosman D., Bonjour J-P.: Dual energy X-ray absorptiometry of lumbar spine and proximal femur in the diagnosis and follow-up of osteoporosis. Am. J. Med. 98: 33S-35S, 1995.

2.Cummings S.R., Black D.M., Nevitt M.C.: Appendicular bone density and age predict hip fracture in women. JAMA 263: 665-668, 1990.

3.Cummings S.R., Nevitt M.C., Browner W.S., Stone K., Fox K.M., Ensrud K.E., Cauley J., Black D., Vogt T.M.: Risk factors for hip fracture in white women. N. Engl. J. Med. 332: 767-773, 1995.

4.Seeman E., Hopper J.L., Bach L.A,, Cooper M.E., Parkinson E., McKay J., Jerums G.: Reduced bone mass in daughters of women with osteoporosis. N. Engl. J. Med. 320: 554-558, 1989.

5.Kelly P.J., Morrison N.A., Sambrook P.N., Nguyen T.V., Eisman J.A.: Genetic influences on bone turnover, bone density and fracture. Eur. J. Endocrinol. 133: 265-271, 1995.

6.Pocock N.A., Eisman J.A., Hopper J.L., Yeates M.G., Sambrook P.N., Ebert S.: Genetic determinants of bone mass in adults. A twin study. J. Clin. Invest. 80: 706-710, 1987.

7.Tylavsy F.A., Bortz A.D., Hancock R.L., Anderson J.J.B.: Familial resemblance of radial bone mass between premenopausal mothers and their college-age daughters. Calcif. Tissue Int. 45: 265-272, 1989.

8.Slemenda C.W., Christian J.C., Williams C.J., Norton J.A., Johnston C.C.: Genetic determinants of bone mass in adult women: a reevaluation of the twin model and the potential importance of gene interaction on heritability estimates. $J$. Bone Miner. Res. 6: 561-567, 1991.

9.Krall E.A., Dawson-Hughes B.: Heritable and life-style determinants of bone mineral density. J. Bone Miner. Res. 8: 1-9, 1993.

10.Seeman E., Hopper J.L., Young N.R., Formica C., Goss P., Tsalamandris C.: Do genetic factors explain associations between muscle strength, lean mass, and bone density? A twin study. Am. J. Physiol. 279: E320-E327, 1996.

11.Ferrari S., Rizzoli R., Slosman D., Bonjour J-P.: Familial resemblance for bone mineral mass is expressed before puberty. J. Clin. Endocrinol. Metab. 83: 358-361, 1998.

12.Bonjour J-P., Theintz G., Buchs B., Slosman D., Rizzoli R.: Critical years and stages of puberty for spinal and femoral bone mass accumulation during adolescence. J. Clin. Endocrinol. Metab. 73: 555-563, 1991.

13. Theintz G., Buchs B., Rizzoli R., Slosman D., Clavien H., Sizonenko P.C., Bonjour J-P.: Longitudinal monitoring of bone mass accumulation in healthy adolescents: evidence for a marked reduction after 16 years of age at the level of lumbar spine and femoral neck in female subjects. J. Clin. Endocrinol. Metab. 75: 1060-1065, 1992.

14.McKay H.A., Bailey D.A., Wilkinson A.A., Houston C.S.: Familial comparison of bone mineral density at the proximal femur and lumbar spine. Bone Miner. 24: 95-107, 1994.

15.Delmi M., Rapin C.H., Bengoa J.M., Delmas P.D., Vasey H., Bonjour J-P.: Dietary supplementation in elderly patients with fractured neck of the femur. Lancet 355: 1013-1016, 1990.

16. Tkatch L.J., Rapin C.H., Rizzoli R., Slosman D., Nyddeger V., Vasey H., Bonjour J-P.: Benefits of oral supplementation in elderly patients with fracture of the proximal femur. J. Am. Coll. Nutr. 11: 519-525, 1992.
17.Schurch M.A., Rizzoli R., Vadas L., Slosman D., Bonjour J-P.: Protein supplements in elderly with a recent hip fracture increase serum IGF-1, decrease urinary deoxypyridinoline and prevent proximal femur bone loss. J. Bone Miner. Res. 11 (Suppl. 1):177, 1996.

18.Chapuy M.C., Arlot M.E., Duboeuf F., Breen J., Crouzet B., Arnaud S., Delmas P.D., Meunier P.J.: Vitamin D3 and calcium to prevent hip fractures in elderly women. N. Engl. J. Med. 327: 1637-1642, 1992.

19.Chevalley T., Rizzoli R., Nyddeger V., Slosman D., Rapin Ch., Michel J.P., Vasey H., Bonjour J-P.: Effect of calcium supplements on femoral bone density and vertebral fracture rate in vitamin D-replete elderly patients. Osteoporos. Int. 4: 245-252, 1994.

20.Dawson-Hughes B., Harris S.S., Krall E.A., Dallal G.E.: Effect of calcium and vitamin D supplementation on bone density in men and women 65 years of age or older. N. Engl. J. Med. 337: 670-676, 1997.

21.Cumming R.G., Nevitt M.C.: Calcium for prevention of osteoporotic fractures in postmenopausal women. J. Bone Miner. Res. 12: 1321-1329, 1997.

22.Fujita T.: Vitamin D in the treatment of osteoporosis revisited. Proc. Soc. Exp. Biol. Med. 212: 110-115, 1996.

23.Kanis J.: Calcium nutrition and its implications for osteoporosis. Part II. After menopause. Eur. J. Clin. Nutr. 48: 833841, 1994.

24.Ott S.M.: Attainment of peak bone mass. J. Clin. Endocrinol. Metab. 71: 1082A-1082C, 1990.

25.Kanis J.: Calcium nutrition and its implications for osteoporosis. Part I. Children and healthy adults. Eur. J. Clin. Nutr. 48: 757-767, 1994.

26.Johnston C.C., Miller J.Z., Slemenda C.W., Reister T.K., Hui S., Christian J.C., Peacock M.: Calcium supplementation and increases in bone mineral density in children. N. Engl. J. Med. 327: 82-87, 1992.

27.Lloyd T., Andon M.B., Rollings N., Martel J.K., Landis J.R., Demers L.M., Eggli D.F., Kiesehorst K., Kulin H.E.: Calcium supplementation and bone mineral density in adolescent girls. JAMA 270: 841-844, 1993.

28.Bonjour J-P., Carrié A.L., Ferrari S., Clavien H., Slosman D., Theintz G., Rizzoli R.: Calcium-enriched foods and bone mass growth in prepubertal girls: a randomized, double-blind, placebocontrolled trial. J. Clin. Invest. 99: 1287-1297, 1997.

29.Housman G.: Human DNA polymorphism. N. Engl. J. Med. 332: 318-320, 1995.

30.Morrison N.A., Yeoman R., Kelly P.J., Eisman J.A.: Contribution of trans-acting factor alleles to normal physiological variability: vitamin D receptor gene polymorphism and circulating osteocalcin. Proc. Natl. Acad. Sci. USA 89: 6665-6669, 1992.

31.Morrison N.A., Qi J.C., Tokita A., Kelly P.J., Crofts L., Nguyen T.V., Sambrook P.N., Eisman J.A.: Prediction of bone density from vitamin D receptor alleles. Nature 367: 284-287, 1994.

32.Peacock M.: Vitamin D receptor gene alleles and osteoporosis: a contrasting view. J. Bone Miner. Res. 10: 1294-1297, 1995.

33.Eisman J.: Vitamin D receptor gene alleles and osteoporosis: an affirmative view. J. Bone Miner. Res. 10: 1289-1293, 1995.

34.Garnero P., Borel O., Sornay-Rendu E., Delmas P.D.: Vitamin $\mathrm{D}$ receptor gene polymorphisms do not predict bone turnover and bone mass in healthy premenopausal women. $J$ Bone 
Miner. Res. 10 1283-1288, 1995.

35.Garnero P., Borel O., Sornay-Rendu E., Arlot M.E., Delmas P.D.: Vitamin D receptor gene polymorphisms are not related to bone turnover, rate of bone loss, and bone mass in postmenopausal women: the OFELY study. J. Bone Miner. Res. 11: 827-834, 1996.

36. Hustmyer F.G., Peacock M., Hui S., Johnston C.C., Christian J.: Bone mineral density in relation to polymorphism at the vitamin D receptor gene locus. J. Clin. Invest. 94: 21302134, 1994.

37.Tokita A., Matsumoto H., Morrison N.A., Tawa T., Miura Y., Fukamauchi K., Mitsuhashi N., Irimoto M., Yamamori S., Miura M., Watanabe T., Kuwabara Y., Yabuta K., Eisman J.A.: Vitamin D receptor alleles, bone mineral density and turnover in premenopausal Japanese women. J. Bone Miner. Res. 11: 1003-1009, 1996.

38.Fleet J.C., Harris S.S., Wook R.J., Dawson-Hughes B.: The Bsm I vitamin D receptor restriction fragment length polymorphism $(\mathrm{BB})$ predicts low bone density in premenopausal black and white women. J. Bone Miner. Res. 10: 985-990, 1995.

39.Houston L.A., Grant S.F.A., Reid D.M., Ralston S.H.: Vitamin D receptor polymorphism, bone mineral density, and osteoporotic vertebral fracture: studies in a UK population. Bone 18 : 249-252, 1996.

40.Uitterlinden A.G., Pols H.A.P., Burger H., Huang Q., Van Daele P.L.A., Van Duijn C.M., Hofman A., Birkenhäger J.C., Van Leeuwen J.P.T.M.: A large-scale population-based study of the association of vitamin $\mathrm{D}$ receptor gene polymorphisms with bone mineral density. J. Bone Miner. Res. 11: 1241-1248, 1996.

41.Jørgensen H.L., Schøller J., Sand J.C., Bjuring M., Hassager C., Christiansen C.: Relation of common allelic variation at vitamin $\mathrm{D}$ receptor locus to bone mineral density and postmenopausal bone loss: cross sectional and longitudinal population study. BMJ 313: 586-590, 1996.

42. Cooper G.S., Umbach D.M.: Are vitamin D receptor polymorphisms associated with bone mineral density? A meta-analysis. J. Bone Miner. Res. 11: 1841-1849, 1996.

43.Sainz J., Van Tornout J.M., Loro M.L., Sayre J., Roe T.F., Gilsanz V.: Vitamin D-receptor gene polymorphisms and bone density in prepubertal American girls of Mexican descent. N. Engl. J. Med. 337: 77-82, 1997.

44.Ferrari S., Rizzoli R., Slosman D., Bonjour J-P.: Do dietary calcium and age explain the controversy surrounding the relationship between bone mineral density and vitamin D receptor gene polymorphisms. J. Bone Miner. Res. 13: 363-370, 1998.

45.Riggs B.L., Nguyen T.V., Melton L.J. III, Morrison N.A., O'Fallon W.M., Kelly P.J., Egan K.S., Sambrook P.N., Muhs J.M., Eisman J.A.: The contribution of vitamin D receptor gene alleles to the determination of bone mineral density in normal and osteoporotic women. J. Bone Miner. Res. 10: 991-996, 1995.

46.Viitanan A.M., Kärkkälnen M., Laitinen K., Lamberg-Allardt C., Kainulainen K., Räsänen L., Viikari J., Välimäki M.J., Kontula $\mathrm{K}$.: Common polymorphism of the vitamin $\mathrm{D}$ receptor gene is associated with variation of peak bone mass in young Finns. Calcif. Tissue Int. 59: 231-234, 1996.

47.Gross C., Eccleshall T.R., Malloy P.J., Villa M.L., Marcus R., Feldman D.: The presence of a polymorphism at the translation initiation site of the vitamin $\mathrm{D}$ receptor gene is associated with low bone mineral density in postmenopausal MexicanAmerican women. J. Bone Miner. Res. 11: 1850-1855, 1996.

48.Harris S.S., Eccleshall T.R., Gross C., Dawson-Hughes B., Feldman D.: The vitamin $\mathrm{D}$ receptor start codon polymorphism (FokI) and bone mineral density in premenopausal American black and white women. J. Bone Miner. Res. 12: 10431048, 1997.

49.Arai H., Miyamoto K.I., Taketani Y., Yamamoto H., Iemori Y., Morita K., Tonai T., Nishisho T., Mori S., Takeda E.: A vitamin $\mathrm{D}$ receptor gene polymorphism in the translation initiation codon: effect on protein activity and relation to bone mineral density in Japanese women. J. Bone Miner. Res. 12: 915-921, 1997.

50.Eccleshall T.R., Garnero P., Gross C., Delmas P.D., Feldman D.: Lack of correlation between start codon polymorphism of the vitamin $\mathrm{D}$ receptor gene and bone mineral density in premenopausal French women: the OFELY study. J. Bone Miner. Res. 13: 31-35, 1998.

51.Ferrari S., Rizzoli R., Manen D., Slosman D., Bonjour J-P.: Vitamin D receptor gene start codon polymorphisms (Fok 1) and bone mineral density: interaction with age, dietary calcium and 3'-end region polymorphisms. J. Bone Miner. Res. 13: 925930, 1998.

52.Kelly P.J., Eisman J.A., Sambrook P.N.: Interaction of genetic and environmental influences on peak bone density. Osteoporos. Int. 1: 56-60, 1990.

53.Ferrari S., Rizzoli R., Chevalley T., Slosman D., Eisman J.A., Bonjour J-P.: Vitamin-D-receptor-gene polymorphisms and change in lumbar-spine bone mineral density. Lancet 345 : 423-424, 1995.

54.Krall E.A., Parry P., Lichter J.B., Dawson-Hughes B.: Vitamin $D$ receptor alleles and rates of bone loss: influences of years since menopause and calcium intake. J. Bone Miner. Res. 10: 978-984, 1995.

55.Ferrari S., Rizzoli R., Chevalley T., Slosman D., Eisman J.A., Bonjour J-P.: Vitamin-D-receptor-gene polymorphisms and change in lumbar-spine bone mineral density - Reply. Lancet 345: 1239, 1995.

56.Kiel D.P., Myers R.H., Cupples A., Kong X.F., Zhu X.H., Ordovas J., Schaefer E.J., Felson D.T., Rush D., Wilson P.W.F., Eisman J.A., Holick M.F.: The BsmI vitamin D receptor restriction fragment length polymorphism (bb) influences the effect of calcium intake on bone mineral density. J. Bone Miner. Res. 12: 1049-1057, 1997.

57.Matsuyama T., Ishii S., Tokita A., Yabuta K., Yamamori S., Morrison N.A., Eisman J.A.: Vitamin D receptor genotypes and bone mineral density. Lancet 345: 1238-1239, 1995.

58.Graafmans W.C., Lips P., Ooms M.E., van Leeuwan J.P.T.M., Pols H.A.P., Uitterlinden A.G.: The effect of vitamin D supplementation on the bone mineral density of the femoral neck is associated with vitamin D receptor genotype. J. Bone Miner. Res. 12: 1241-1245, 1997.

59.Salamone L.M., Glynn N.W., Black D.M., Ferrell R.E., Palermo L., Epstein R.S., Kuller L.H., Cauley J.A.: Determinants of premenopausal bone mineral density: the interplay of genetic and lifestyle factors. J. Bone Miner. Res. 11: 15571565, 1996.

60.Gregg E.W., Wolf R.L., Kriska A.M., Ferrell R.E., Salamone L.M., Black D., Kuller L.H., Cauley J.A.: Does the relationship between vitamin $D$ receptor genotypes and bone parameters vary with physical activity level? J. Bone Miner. Res. 11: (Sup- 
pl. 1): S210, 1996

61.Dawson-Hughes B., Harris S.S., Finneran S.: Calcium absorption on high and low calcium intakes in relation to vitamin D receptor genotype. J. Clin. Endocrinol. Metab. 80: 36573661, 1995.

62.Zmuda J.M., Cauley J.A., Danielson M.E., Wolf R.L., Ferrell R.E.: Vitamin D receptor gene polymorphisms, bone turnover, and rates of bone loss in older African-American women. $J$. Bone Miner. Res. 12: 1446-1452, 1997.

63.Grant S.F., Reid D.M., Blake G., Herd R., Fogelman I., Ralston S.H.: Reduced bone density and osteoporosis associated with a polymorphic $\mathrm{Sp} 1$ binding site in the collagen type I alpha gene. Nat. Genet. 14: 203-205, 1996.

64.Uitterlinden A., Burger H., Huang Q., Yue F., McGuigan F., Grant S., Hofman A., Van Leeuwen J., Pols H., Ralston S.H.: Relation of alleles of the collagen type $1 a ̊ 1$ gene to bone mineral density and the risk of osteoporotic fractures in postmenopausal women. N. Engl. J. Med. 338: 1916-1921,
1997.

65.Kobayashi S., Inoue S., Hosoi T., Ouchi Y., Shiraki M., Orimo H.: Association of bone mineral density with polymorphism of the estrogen receptor gene. J. Bone Miner. Res. 11: 306311, 1996.

66.Han K.O., Moon G., Kang Y.S., Chung H.Y., Min H.K., Han I.K.: Nonassociation of estrogen receptor genotypes with bone mineral density and estrogen responsiveness to hormone replacement therapy in Korean postmenopausal women. J. Clin. Endocrinol. Metab. 82: 991-995, 1997.

67.Langdahl B.L., Knudsen J.Y., Jensen H.K., Gregersen N., Eriksen E.F.: A sequence variation : 713-8delC in the transforming growth factor-beta 1 gene has higher prevalence in osteoporotic women than in normal women and is associated with very low bone mass in osteoporotic women and increased bone turnover in both osteoporotic and normal women. Bone 20: 289-294, 1997. 